\title{
Auto Plant Closures, Policy Responses and Labour Market Outcomes: a Comparison of MG Rover in the UK and Mitsubishi in Australia
}

\author{
Kathy Armstrong, David Bailey, Alex de Ruyter, Michelle Mahdon and Holli Thomas ${ }^{1}$
}

\begin{abstract}
This paper provides a preliminary comparative longitudinal analysis of the impact on workers made redundant due to the closure of the Mitsubishi plant in Adelaide and the MG Rover plant in Birmingham. Longitudinal surveys of ex-workers from both firms were undertaken over a 12month period in order to assess the process of labour market adjustment. In the Mitsubishi case, given the skills shortage the state of Adelaide was facing, together with the considerable growth in mining and defence industries, it would have been more appropriate if policy intervention had been redirected to further training or re-skilling opportunities for redundant workers. This opportunity was effectively missed and as a result more workers left the workforce, most notably for retirement, than could have otherwise been the case. The MG Rover case was seen as a more successful example of policy intervention, with greater funding assistance available and targeted support available, and with more emphasis on re-training needs to assist adjustment. However, despite the assistance offered and the rhetoric of successful adjustment in both cases, the majority of workers have nevertheless experienced deterioration in their circumstances - particularly in the Australian case where casual and part-time work were often the only work that could be obtained. Even in the UK case, where more funding assistance was offered, a majority of workers reported a decline in earnings and a rise in job insecurity. This suggests that a reliance on the flexible labour market is insufficient to promote adjustment, and that more active policy intervention is needed especially in regard to further up-skilling.
\end{abstract}

\section{INTRODUCTION}

Integrating displaced workers - job quality and well-being

Economic restructuring has been an important feature of the UK and Australian economies in the last 25 years. The processes of deregulation, privatisation, technological change and globalisation have combined to reshape the economic landscape across both countries. Some industries have grown, while others have declined. In particular, there has been a dramatic shift away from manufacturing to the services industries; a process which has been typified by a number of highprofile plant closures across both countries (see Chapain and Murie in this issue).

Whilst the overriding labour market policy emphasis in both countries has been a raw focus on transition into 'any job', successful adjustment and well-being requires that issues of job quality should also be addressed. Graetz (1993) found that the relationship between psychological wellbeing and employment is related to the quality of the employment found. Well-being only improved after re-employment if people went into jobs that they were satisfied with. Similarly it has been found that re-employment into jobs with lower pay or where skills are underutilised does not enhance psychological health relative to that of unemployed persons (Winefield et al, 1990). In contrast, positive psychological health facilitates re-employment following unemployment (Waters and Moore, 2002).

Such research illustrates that the issues surrounding re-integration extend beyond merely providing 'jobs' or 'job opportunities' for displaced workers. They extend to job quality as well as income security. This is particularly pressing for displaced workers who are only able to obtain casual or part-time work after redundancy. Indeed, there is evidence to suggest that individuals who subsequently obtain such work can become 'trapped' in precarious cycles of intermittent work and 
unemployment (Westin, 1990) - further adding to their sense of exclusion and deprivation. The demise of secure jobs in traditional sectors and the shift to part-time and casual ${ }^{2}$ arrangements is a key reason for growing job insecurity in both the UK and Australia in the past 20 years (De Ruyter and Burgess, 2003). Indeed, casual employees now comprise over one-quarter of the Australian workforce (ibid.). Hence, the issues surrounding plant closure also extend to those of individual health and well-being and prospects for lasting career opportunities, not to mention the effects on the household and wider community.

As such, the employment and well-being consequences of closure are considerable, and need to be explored through longitudinal studies. Yet few studies (e.g., Westin, 1990; Leana and Feldman, 1995) have explicitly looked at the employment outcomes and the quality of jobs entered into over the longer term. As Leana and Feldman (1995: 1385) note, most of the research on plant closure "has taken as its end point re-employment; when laid-off workers get new jobs, they typically cease to be the focus of further research". It is the employment quality impacts of these closures on ex-MG Rover workers in the UK and Mitsubishi workers in Australia that this article seeks to explore. The rationale for this is that the similarities in the profile of ex-workers and the similar problems of adjustment for manufacturing apparent in Australia (Beer et al, 2004) and the UK (Bailey and Kobayashi, 2006) provide an excellent opportunity to compare differences in the nature and effectiveness of different policy responses. The following sections describe the policy responses and labour market outcomes of the respective closures in Australia and the UK. In this paper, we focus on one aspect of employment and well-being - the degree of income and employment security of jobs entered into (De Ruyter and Burgess, 2003). The paper ends with a comparison of the two cases with a view to expounding some lessons for policy.

\section{THE AUSTRALIAN CASE: MITSUBISHI IN ADELAIDE}

This section examines the closure of the Mitsubishi Lonsdale plant in Adelaide. The background to the plant's closure and the nature of the policy response is detailed in the introduction to this special issue.

\section{Government Policy Responses aimed at Labour Market Assistance}

When Mitsubishi Motors Australia Limited announced that it was closing its Lonsdale manufacturing plant, along with voluntary redundancies at its Tonsley Park assembly plant, the Federal and State governments responded with two main packages of assistance for the 1200 workers affected. The Structural Adjustment Fund for South Australia (SAFSA) was a pooled fund into which the Federal Government committed \$40 million (around £18 million at January 2008 exchange rates) and the South Australian Government committed \$5 million (just over £2 million). The SAFSA was effectively a capital subsidy, offering grants to new businesses wanting to invest in South Australia or existing businesses that wanted to expand their business in South Australia.

The rationale from government for adopting this measure of assistance was that the expansion of business would create new jobs in the region that could absorb displaced Mitsubishi workers. While there have been numerous businesses established on the Lonsdale site through SAFSA funding, the government has been forced to admit that the majority of firms who received grants have not achieved their employment targets. Furthermore, over half of the SAFSA funding went to businesses on the northern side of the city when virtually all of the displaced Mitsubishi workers lived in the southern region. The main labour market response from government to the redundancies at Mitsubishi was the Labour Adjustment Package (LAP). The Federal Government committed \$10 million (around $£ 4.5$ million) of funding for the LAP with the State Government only contributing a range of services to support the LAP, including financial counselling, CV / resumé preparation and career counselling that totalled \$383,485 (around £170k). 
The $\$ 10$ million funding amounted to approximately $\$ 10,000$ (around $£ 4500$ ) per worker. The LAP was delivered through the privately run Job Network agencies. The Mitsubishi LAP provided an additional $\$ 450$ per worker to Job Network providers so that they could purchase further services or assistance such as tools, uniform, clothing or training. The LAP was designed to give additional assistance to help displaced Mitsubishi workers find new employment. As part of this assistance all Mitsubishi workers facing redundancy were fast-tracked onto the Intensive Support Customised Assistance (ISCA) scheme. This was an existing program used to assist long term unemployed people. This section of the paper focuses on LAP support as the SAFSA scheme has been discussed in more detail by Thomas and Beer in this special issue.

Both government responses in the Mitsubishi case amount to a minor intervention, especially when compared to previous government interventions in the automotive industry, or to the response to the closure of MG Rover in the UK described in the following section. Both the Federal and State Governments have made it clear that they do not see the role of government to be "propping up" manufacturing industries that are no longer competitive. The redundancies at Mitsubishi came when the State of South Australia was experiencing a boom in the mining and defence industries. The assumption made by government was that Mitsubishi workers would be able to move seamlessly into jobs in mining and defence. As South Australian Premier Mike Rann recently commented:

When we saw Lonsdale close, we were able to find jobs for nearly all of the people who wanted jobs because of other things that were happening...A lot of people who build the actual hulls and things associated with the defence industry will be coming out of car industry jobs (The Adelaide Advertiser, 2007)

It is of importance, then, to critically assess these types of claims and examine to what extent successful labour market reintegration (that is, re-entry into permanent, full-time employment) has actually occurred. In addition, given previous research outlined in the introduction, it is vital to assess the quality of these new jobs as 'good jobs' are linked to better health outcomes providing beneficial long term effects to the economy.

\section{Labour Market Outcomes for Redundant Mitsubishi Workers}

This article uses qualitative data collected during the 12 months after redundancy to assess the employment outcomes for Mitsubishi workers made redundant between 2004 and 2005. 373 workers participated in wave 1 and 315 were interviewed in wave 2 which occurred approximately 12 months post-redundancy. The findings are part of a longitudinal study into the health, housing and labour market impacts of job losses in the automotive sector within southern Adelaide (see Beer et al, 2006). The study as a whole involved three waves of quantitative data collection and two waves of qualitative data collection over a period of 18 months.

It is important to recognise that, whilst at Mitsubishi, all respondents were employed on a permanent full-time basis. However, 12 months post-redundancy only 34 percent of displaced workers were in full time employment. Furthermore, over 20 percent of respondents were in casual or part-time employment, with some 69 percent of those in casual employment reporting that they would rather be working full-time. These figures indicate a significant level of under-employment among displaced Mitsubishi workers. Many respondents reported they struggled to find full-time employment and had to settle for casual or part-time contract positions. The difficulty these displaced workers faced in finding new employment is illustrated through the fact that 66 percent of respondents reported that they were unemployed at some stage during the 12 months since leaving Mitsubishi. 
Significantly over 30 percent of respondents did not participate in the workforce 12 months postredundancy. This included 13 percent who were unemployed looking for work, 9 percent who had retired and 4 percent who were not working because of a disability. This represents a high level of unemployment among displaced workers, especially when compared to the State's unemployment rate which was 4 to 5 percent during the same period. Our research suggests that the considerable percentage of workers who withdrew from the labour market hides the true extent of unemployment and under-employment amongst the displaced workers. For instance, 28 percent of those who had retired said that they would rather be working, but they had been unable to find new employment. A common complaint from respondents was that they were unable to find full-time employment. One respondent remarked 'casual employment sucks, its darn hard to get a full-time job', while another commented 'I'm very frustrated I can't get a full-time job, the pay is a lot less and there is constant uncertainty in not knowing when a contract will end'.

Some 71 percent of respondents reported that they were now earning less that when employed at Mitsubishi. This is partly a result of the shift from full time to part time or casual work for many displaced workers. However, it also reflects the reality that Mitsubishi was recognised as a good employer, who paid above the market rate. Moreover, Mitsubishi also appears to have provided good working conditions for its employees. Most displaced workers have found lower pay and poorer working conditions in their new employment. Of those in full-time employment 31 percent reported that their current job was worse than their job at Mitsubishi, while 41 percent of those in casual employment found their current job worse than their job at Mitsubishi. For those in casual employment, when asked the worst thing about their current job, the most common complaint was that they were not getting enough hours or pay.

The number of jobs respondents have had in the 12 months since leaving Mitsubishi also indicates dissatisfaction with new employment. Of those in new employment, many had already had more than one job, with 39 percent of those who found employment reporting they had two jobs, 20 percent reporting three jobs and 14 percent reporting they had more than three jobs since leaving Mitsubishi. This indicates the insecurity of the jobs that displaced workers have entered, with many reporting that they were made redundant again in their new employment, or that they were only employed on a short term contract and were therefore forced to find other work when that finished. Indeed many respondents reported that they were simply going from one short term contract to another, as that was the only employment they could find. Many respondents also faced considerable periods of unemployment in between jobs. For instance one respondent reported:

I've had a few jobs since leaving Mitsubishi...they were all part-time and contract...it took me three months to find a job. After nine months of contract it faded out. I found another job six weeks later.

Previous research has shown job security is an important factor in a 'good job' with a positive influence on an employee's state of health (Marmot, 2004).

Displaced workers found new employment across a diverse range of industries, though 36 percent of respondents reported that they were currently working in manufacturing. Other industries where a significant number of displaced workers had found employment included: 11 percent in retail; 7 percent in construction; 6 percent in health services and 4 percent in agriculture.

Despite the rhetoric from government that former Mitsubishi workers had been absorbed by new employment in the booming mining and defence industries, only 2 percent were employed at the time of the survey in industries related to mining, and another 2 percent were employed in industries related to defence. The explanation lies in the fact that displaced workers were not provided with the necessary education and training opportunities to equip them with the skills required to be able to move into employment in the mining and defence industries. No funds were 
set aside by either Federal or State government for re-training or up-skilling redundant Mitsubishi workers, despite the Government of South Australia recognising the state was suffering a skills shortage (Government of South Australia, 2005). This stands in stark contrast to the $£ 50$ million that the UK Government put aside specifically for training and re-skilling of redundant workers from MG Rover (RTF, 2006). Redundant Mitsubishi workers needed greater intervention and assistance from government, in the form of substantial training and education, to enable them to move into the employment being created in growth sectors such as defence and mining.

In Australia the funds for the labour adjustment assistance were channelled into the privately run Job Network agencies who were then responsible for delivering assistance to displaced workers in finding new employment. It does not appear that this was an efficient use of resources or an effective policy given that 38 percent of respondents reported that they did not use the Job Network providers. Of those currently employed, only 6 percent reported that they got their job through Job Network agencies. Of those who did use the Job Network provider, their reported experience was one of disappointment and frustration as they felt that the Job Networks were more used to dealing with the long-term unemployed, rather than skilled workers with a long work history. A common complaint was that the Job Network agencies did not put forward suitable jobs. For instance one respondent reported that:

they [the Job Network provider] told me that I was over-qualified, that the Job Network didn't have the resources to find relevant jobs for someone like me.

This left a sense of dissatisfaction amongst displaced workers who questioned where the \$10 million of funding had gone. For instance one respondent reported:

I'm very disappointed in the number of job opportunities in the southern area. Job Network agencies are absolute rubbish. They abuse us and rip us off. The same agencies don't do a good job... We are just a commodity and they rip us off big time. We get bad pay and they pocket [the money].

It would appear that the Job Network agencies did not have the resources to deal with skilled workers and placing redundant Mitsubishi workers on an existing scheme designed to assist the long-term unemployed was an inappropriate response by government. Given that the majority of redundant Mitsubishi workers did not use a Job Network agency and that very few of the individuals who did use them actually managed to find employment through the Job Network agencies, it is evident that the Labour Adjustment Package was not effective in assisting these displaced workers to regain employment. Furthermore, the \$10 million LAP was divided between the Job Network providers according to how many redundant Mitsubishi workers had signed up with them. The Job Network providers then had the discretion to decide how much money was spent on each individual and for what purposes. This was at best an ad-hoc system where the Job Network providers were simply the administrator of the LAP, which no doubt led to a considerable amount of the $\$ 10$ million LAP being consumed in administration costs.

Given the skills shortage the state was facing, together with the considerable growth in mining and defence industries, it would have been more appropriate if LAP funding had been redirected to further training or re-skilling opportunities for redundant workers. Lack of training and re-skilling for redundant workers also partly explains why so many former Mitsubishi workers have only been able to find new employment in lower paid positions with less security of employment, as evidenced by those who could only obtain casual work. While government has claimed the number of Mitsubishi workers in new employment marks the success of their assistance packages, this masks the reality that over 70 percent of those redundant workers are now earning less than they were at Mitsubishi; that over 20 percent have gone from permanent full-time employment to part- 
time or casual employment; that over 30 percent of redundant workers withdrew from participating in the labour force; and that most of these redundant workers are now faced with insecure employment, many of them having had several jobs in the year after leaving Mitsubishi.

\section{THE UK CASE: MG ROVER IN BIRMINGHAM}

This section examines the demise of MG Rover and government policy and subsequent labour market outcomes, utilising the results of two waves of a longitudinal survey of ex-MG Rover (MGR) workers conducted by The Work Foundation (see Armstrong, 2006 for a more detailed discussion). The background to the MG Rover closure is covered by Bailey et al in this issue.

\section{Government Policy Responses aimed at Labour Market Assistance}

Phoenix Venture Holdings (the owners of MGR) went into administration in April 2005, precipitating the sudden closure of the MGR plant at Longbridge, in Birmingham. Immediately, some 5,500 MGR workers were made redundant (with several thousand more jobs threatened at suppliers of MGR). As such, the closure of MGR had significant adverse consequences for the West Midlands region, as the firm's turnover accounted for 0.5 to 1 percent of regional GDP; with $£ 200$ million a year alone in government revenue foregone, in addition to multiplier effects within the supply chain (Bailey and Kobayashi, 2006).

Much of the immediate policy response to the closure of MGR was that of 'crisis management', focusing on jobs and short-term financial assistance, under the auspices of the Second Rover Task Force (Bailey and Kobayashi, 2006). The Rover Task Force comprised organisations including Advantage West Midlands, the Birmingham Chamber of Commerce, JobCentre Plus, the Learning and Skills Council, Birmingham City Council, other Local Authorities, trade unions, community groups and industry bodies. An aid package worth $£ 176$ million was made available, including $£ 50$ million for retraining (up to NVQ level 2 skills), $£ 40$ million in redundancy payments, a $£ 24$ million loan fund to help otherwise viable businesses, and £41.6 million to support ex-MGR suppliers to remain viable. Another $£ 7.6$ million was announced by AWM in June 2005 to further assist with supplier diversification (RTF, 2006).

The focus of the RTF was to facilitate diversification in the supply chain, support ex-MGR workers to find new jobs, and provide assistance to the wider community (Armstrong, 2006). A telephone hotline for ex-MGR workers was implemented, in addition to a website providing advice and contact details for MGR suppliers, employees and the local community. A helpline was also established by the Birmingham City Council to provide support for local residents. An MGR Jobcentre Plus hotline was launched to provide advice on job opportunities and benefits available. A package of tailored support for suppliers was also developed. Other initiatives included providing travel subsidies for workers having to commute greater distances to work, free training for wives and partners of ex-MGR workers and free training in manufacturing re-skilling (ibid.). Hence, it is apparent that (in contrast to ex-Mitsubishi workers) there has been significant assistance to ex-MGR workers. However, has this assistance translated into 'successful' labour market outcomes?

\section{Labour Market Outcomes}

In this section we seek to assess the effectiveness of government policy and the consequent nature of labour market adjustment by ex-MGR workers, based on data from both The Work Foundation surveys referred to earlier and data reported by the RTf (2006). The first wave of the survey took place three months after the closure in July 2005 and the second in December 2005. In the first wave, 273 interviews were conducted with ex-MGR workers. In the second wave, 232 interviews (86 percent of the original sample) were conducted. The demographic profile of the sample was 
reasonably representative of the MGR workforce according to gender, age, department and length and service.

At the time of the first wave (July 2005), 60 percent of the sample were unemployed and looking for work. At wave 1, only a quarter of the sample had found full-time work. Of those who had found a job, 52 percent liked their new job and considered themselves as doing it for the foreseeable future. However, more than a third (37 percent) saw their new job as a stopgap until something better came along. A large number, 25 percent of the sample, were not aware that MGR workers were entitled to re-skilling in a manufacturing skill. Only 29 percent of the total sample had taken advantage of the re-skilling opportunity.

Six months after the closure (Wave 2: December 2005) 34 percent of the survey sample were still unemployed and looking for work. More than half of the sample were now employed fulltime; a significant change in the employment status of the sample. Essentially, a majority of those who were unemployed at wave 1 had obtained full-time work at wave 2 . The numbers of those in education or training, those who were self-employed, or those employed part-time did not change significantly between the two waves (Armstrong, 2006). In aggregate, results from the RTF (2006), revealed that by February 2006 (approximately one year after closure), of approximately 6,300 claimants resulting directly from the collapse, around 4,000 were back in work (90 percent full-time, in apparent contrast to the case with ex-Mitsubishi workers in Adelaide where some two thirds of ex-employees were still unemployed 12 months post closure), 667 were in training or awaiting training, 398 had received training but were still not working, 530 were not working and had not received any training, 443 had unknown destinations and 257 had claimed alternative benefits after claiming Job Seekers’ Allowance (RTF, 2006).

Close to half of the workers (46 percent) in The Work Foundation survey wave 2 (Armstrong, 2006: 18) found themselves doing very different jobs using very different skills compared to when they were at MGR. Although workers had found jobs in a wide variety of sectors, many had found jobs in similar sectors to before (manufacturing and the motor industry) even if they were now using different skills. The sectors where ex-MGR workers had obtained work by February 2006 were (from most to least common): manufacturing; motor industry; transport; engineering; construction; local government; the NHS; government; delivery; retail; security; and financial services (ibid.). On one level, this can be interpreted as a relatively successful policy response in enabling structural change and assisting workers back into employment. However, there has been a high degree of competition for jobs in certain sectors. As one regional development officer commented,

'In this area there [has been] a large influx of ex-Rover workers all vying for the same jobs. I'd say for every job there [were] 50 applicants'

For those individuals still unemployed six months after closure (Work Foundation survey Wave 2), health and poor self-esteem were ongoing issues; particularly for the older workers (unemployment at wave 2 was highest in the $45-54$ age group, at 41 percent). Those in part-time education or training reported the largest decreases in their state of health. Those who were unemployed were much more likely to report than those employed that health problems were interfering with their ability to carry out normal tasks (Armstrong, 2006: 19). It was interesting to note that 205 ex-MGR workers who initially claimed Job Seekers Allowance had since made claims to Incapacity Benefit. This suggests that there appear to have been impacts on the health of unemployed workers in the initial six months following the closure.

Even for those who had regained employment by February 2006, the situation was far from positive; nearly two thirds of the workers who had found work in October 2005 had a lower salary (RTF, 2006). Nearly half of the workers in The Work Foundation survey Wave 2 sample (47 
percent, six months post closure) thought that their current job was worse than their job at MGR (Armstrong, 2006: 27). It appears that a majority of the low-skilled MGR workers who had been used to 'middling' jobs were now finding that the majority of the employment opportunities were at the bottom of the hourglass (and hence perhaps more akin to the 'casual' employment arrangements that were a common destination for the redundant Mitsubishi workers detailed in the Australian study). The jobs they had at MGR were relatively well paid, considering the skill levels required (again comparable with the Australian study). In part this was a tribute to the effectiveness of unions in collective bargaining, which has traditionally had the effect of improving the pay position of less-skilled/lower-paid workers (Metcalf et al, 2001). For many, working at MGR was a positive experience and it was a workplace where they felt valued and enjoyed their work. Their experience of work is completely different post-MGR. As one worker commented,

'...family and friends have felt sorry for me because I am no longer able to do a job which I felt pride and job satisfaction in.'

As such, the legacy of being part of a highly unionised workforce was not without its problems, in terms of job search. Many survey respondents reported that their experience of job search had been clouded by the perception of potential employers that they were unproductive trouble-makers. As another worker commented

'I had been talking to one guy at a company which had some openings who had said his management wouldn't be considering ex-MG Rover workers because of the reputation they felt they had, due to the bad press over the years of how Rover workers were meant to lazy and how they wanted the maximum out while putting the minimum in.'

This highlights some of the broader structural problems in the local economy and the difficulty involved in successfully re-integrating displaced workers back into quality permanent employment.

As such, whilst the costs of closure have fallen most heavily on those unable to shift into new employment, it is apparent from the preceding discussion that even those back in work have experienced substantial losses. The majority of workers were now earning significantly less than they did at MGR - £3,523 a year less on average for those who were working full-time and on average $£ 10,153$ a year less for those who were now working part-time. The anxiety levels associated with this loss were considerable; particularly for those constrained to take part-time work. While those working part-time in the survey sample had a much lower ratio of job applications to job offers compared to other workers. It appeared from their anxiety levels, that many were still plagued by financial and other concerns. One could surmise that these workers were not working part-time by choice. Rather they were accepting what employment they could obtain and as such, were under-employed. One worker commented that 'I feel uncertain of everything, I don't feel I can plan or commit'. This anxiety appeared to be affecting the families of workers - another worker commented that

'My wife took it as a bereavement, burst out crying, my young son started bed wetting again and my daughter became very stressed and highly strung.'

Older workers also experienced a larger salary differential than younger workers, perhaps due to the fact that they were no longer being paid for their length of service. Those workers who stayed in the manufacturing sector tended to earn less than those who went into other sectors such as education, health or services. 
Thus, despite the rapid policy response to the closure and assistance offered to ex-MGR workers, for a significant group problems remain in facilitating successful labour market transition and wellbeing.

\section{DISCUSSION: COMPARATIVE ASPECTS OF THE CLOSURES AND LESSONS FOR POLICY}

This article has demonstrated that despite the rhetoric of flexible labour markets and successful adjustment from the effects of plant closure for both ex-Mitsubishi and ex-MGR workers, it is evident that the majority of workers in both countries have not experienced an improvement in their labour market status. Rather, for many, the experience of adjustment has been overwhelmingly negative, with a loss of income and a rise in employment insecurity.

Apparent from this study (and previous studies) is that the effects of unemployment could last longer than the period of unemployment itself, and that once a person has been unemployed once, the risk of being trapped in a precarious cycle of further spells of unemployment are increased. Those with a history of unemployment are more likely to be reemployed into insecure and/or poorquality jobs. Westin (1990) found strong evidence of this in a 10-year longitudinal study of workers affected by of the closure of a sardine plant in Norway. The employment patterns of this group were compared with a group of workers in a 'sister' sardine factory that remained open over the 10-year period. Most notable was the extent to which those who lost their jobs continued to be profoundly affected by the event. Even after 10 years, they spent less time in paid work than those at the 'sister' factory, had consumed considerably more disability benefits - and many had left the labour force for good (ibid.). In this context, a lack of active government intervention in the (flexible) labour market would only reinforce the overriding tendencies towards polarisation and exclusion characteristic of liberal market economies such as Australia and the UK (De Ruyter and Burgess, 2003).

Governments need to consider how to help the workforce adapt to ongoing changes in industrial structure. A key issue here in both countries is the rapid shift away from mass manufacturing towards smaller-scale high value-added work. For example, services in Birmingham now account for 80 percent of jobs. These have been quite diverse jobs, with some in high-paying professional services, whilst others are relatively low-paid (often part-time and/or casual) jobs in retail or wholesaling (BSEDF, 2005). Unemployment in Birmingham remains high relative to the national average, with a local claimant count of $8.1 \%$ against a national average of $2.9 \%$ in December 2007 (Birmingham City Council, 2008, using ONS figures), concentrated in pockets of deprivation. A real legacy effect is the absence of a "widespread culture of studying for qualifications" (BSEDF, 2005). In both locations (Adelaide and Birmingham), a weak skills base acts as a dampener on economic development. Approximately 22 percent of the working age population in Birmingham had no qualifications in 2006, compared to 15 percent for the rest of the UK (ONS, 2006). ${ }^{3}$ Similarly in southern Adelaide the percentage of working age population with qualifications is significantly lower than the state and national average. This partly explains why despite Australia having near full employment, higher levels of underemployment and unemployment remain in the Southern region of Adelaide than other parts of the nation. Hence, evident is the need for a much greater effort in terms of cross-training initiatives in both countries to suit emerging employment opportunities.

A key issue for government then is whether 'bad' jobs can be turned into 'good' jobs. Moreover, can government ensure future closure policies help create high quality jobs for displaced workers. A more focussed and sophisticated effort needs to be made in both countries to improve the wages of the working poor that goes beyond a reliance on the minimum wage. In the UK, the wages of 
the very low paid were supplemented with tax credits, with those on minimum wages able to receive the maximum entitlements (see Burgess et al, 2007). This is commendable and has greatly assisted those at the bottom of the labour market. However, more needs to be done to give the lower-paid a genuine living wage and make work pay - an issue not lost on ex-workers themselves, as one ex-MGR worker commented, 'The job I've been offered would make me less well off than receiving benefits.' As such, regional development agencies need to consider the promotion of high-quality and healthier work as part of their strategies for sustainable economic development. These agencies need to be supported by central government in this direction, which could require a redirection of funding. Indeed, a national agenda for the promotion of higher quality employment depends on practical delivery at a regional level in both countries.

Finally, the ongoing hollowing-out of manufacturing in both countries suggests a renewed role for industrial policy. It is here that the policy record of both countries is perhaps at its weakest. This needs to be recognised for the development of future industrial policy, given that the latter is now 'back on the agenda' in some sense. An important criticism of the UK government (notably the former Department of Trade and Industry, DTI) was that it took so long to realise that MGR was struggling and then rushed into contingency planning that focused too much on how to deal with a collapse of the firm (NAO, 2006). It was clear to many analysts that MGR was selling off its assets (land, parts business, finance arm and later its intellectual property rights) in an increasingly desperate attempt to continue operations. In fact, the DTI was not capable of recognising this as on-going monitoring of strategic companies is not what it considered a relevant part of modern industrial policy (Bailey, 2003). ${ }^{4}$ In Australia the government similarly appeared completely unprepared as to how to respond to the closure of Mitsubishi at Lonsdale, even though there had been clear warning signs of the imminent closure for years. The government response to the closure of Mitsubishi at Lonsdale was rushed and ad-hoc and not very effective. Yet despite this, the package of assistance for Mitsubishi has become the standard 'roll out' government response to redundancies that have occurred in Australia such as at Holden Motors, Electrolux and Ford. It is surprising that so little reflection or critical assessment of these policies has occurred within government. As such, there are important lessons to be learnt for industrial policy design and delivery.

Whilst we have focused on employment and income security in this paper, there are other aspects of work and well-being that also need to be explored; for example, issues relating to health, autonomy and discretion in the workplace, and skill use. Hence, further research is required on the employment and well-being implications of plant closure and labour market restructuring.

\section{CONCLUSION}

This paper has provided a preliminary comparative longitudinal analysis of the impact on workers made redundant due to the closure of the Mitsubishi plant in Adelaide and the MG Rover plant in Birmingham. In the Mitsubishi case, given the skills shortage the state was facing, together with the considerable growth in mining and defence industries, it would have been more appropriate if intervention in the form of Labour Adjustment Package (LAP) funding had been redirected to further training or re-skilling opportunities for redundant workers. This opportunity was effectively missed and as a result more workers left the workforce, most notably for retirement, than could have otherwise been the case. The MG Rover case was seen as a more successful example of policy intervention (see also Thomas et al in this issue), with greater funding assistance available and targeted support available, and with more emphasis on re-training needs to assist adjustment. However, despite the assistance offered and the rhetoric of successful adjustment in both cases, the majority of workers have nevertheless experienced a deterioration in their circumstances particularly in the Australian case where casual and part-time work were often the only work that could be obtained. Even in the UK case, where more funding assistance was offered, a majority of 
workers reported a decline in earnings and a rise in job insecurity. Job insecurity is one factor known to have a negative influence on well-being.

This suggests that a reliance on the flexible labour market is insufficient to promote adjustment, and that even more active policy intervention is needed especially in regard to further up-skilling. For many, reliance on flexible labour markets only reinforces the polarisation and exclusion referred to earlier. The evidence from Westin's 1990 study casts doubt on the probability of displaced workers finding good quality jobs in the long term without appropriate government intervention. Hence, there is a need for further longitudinal studies to better understand long-term employment prospects for workers so strongly affected by plant closures as deindustrialisation continues. $^{5}$

\section{REFERENCES}

ARMSTRONG, K. (2006) Life after MG Rover: The impact of the closure on the Workers, their Families and the Community. London: The Work Foundation; report prepared for BBC Radio 4.

BAILEY, D. (2003) Globalisation, Regions and Cluster Policies: The Case of the Rover Task Force, Policy Studies, 2003, Vol.24, No.2/3.

BAILEY, D and DRIFFIELD, N (2007) Industrial Policy, FDI and Employment: Still 'Missing a Strategy, Journal of Industry, Competition and Trade, 2007, Vol.7, Iss.2.

BAILEY, D. and KOBAYASHI, S. (2006) Crisis and Restructuring in the West Midlands Auto Cluster Institute for Economic Development Policy Discussion Paper, 2006-06.

BEER, A., MAUDE, A., and PRITCHARD, B. (2003) Developing Australia's Regions: Theory and Practice, Sydney: University of NSW Press.

BIRMINGHAM CITY COUNCIL (2008) Unemployment Briefing. Available at:

http://www.birminghameconomy.org.uk last accessed 18/01/2008

BSEDF (Birmingham and Solihull Economic Development Forum). 2005. Economic Review 2005/6. Birmingham: Birmingham and Solihull Economic Development Forum.

BURGESS, J., DE RUYTER, A., WARING, P. and WARNECKE, T. (2007) 'The Minimum Wage in Three Neo-Liberal Settings: Understanding the Rationale and the Processes' Paper presented to the British Journal of Industrial Relations ' 100 Years of the Minimum Wage' conference, London School of Economics, December 13-14.

DE RUYTER, A. and BURGESS, J. (2003) 'Growing Labour Insecurity in Australia and the UK in the Midst of Jobs Growth: Beware the Anglo-Saxon Model!' European Journal of Industrial Relations, 9 (2): 223-43.

GOVERNMENT OF SOUTH AUSTRALIA, (2005) Global Horizons, Local Initiatives: A Framework for South Australia’s Manufacturing Future, Adelaide.

GRAETZ, B. (1993) 'Health consequences of employment and underemployment: longitudinal evidence for young men and women' Social Science and Medicine, 35, (6): 715-24.

LEANA, C. and FELDMAN, D. (1995) 'Finding new jobs after a plant closing: Antecedents and outcomes of the occurrence and quality of reemployment' Human Relations, 48 (12): 1381-1401. MARMOT, M. (2004). Status Syndrome. London: Bloomsbury.

METCALF, D. ET AL, (2001) 'Unions and the Sword of Justice: Unions and Pay Systems, Pay Inequality, Pay Discrimination and Low Pay’ National Institute Economic Review.

HOUSE OF COMMONS. TRADE AND INDUSTRY COMMITTEE (2007) Success and Failure in the UK Car Manufacturing Industry. Fourth Report of Session 2006-07. Report together with formal minutes, oral and written evidence. HC399. London: The Stationery Office. March 2007. MG ROVER TASK FORCE (RTF), (2006) Final Update Report: The Work Goes On, prepared for the Department of Trade and Industry. March 2006. 
NAO (NATIONAL AUDIT OFFICE). 2006. The Collapse of MG Rover. HC961 Session 2005-6. London: The Stationery Office.

ONS (2006) 'Labour Market Profile: Birmingham' Nomis Official Labour Market Statistics, Office of National Statistics. http://www.nomisweb.co.uk Last accessed 04/11/07.

PIKE, A. (2005) 'Building a Geographical Political Economy of Closure: The Case of R\&DCo in North East England’ Antipode, 39 (1): 93 - 115.

TOMANEY J., PIKE, A. and CORNFORD, J. (1999) 'Plant closure and the local economy: The case of Swan Hunter on Tyneside.’ Regional Studies, 33(5): 401-11.

WATERS, L. and MOORE, K. (2002) 'Self-esteem, appraisal and coping: a comparison of unemployed and re-employed people’ Journal of Organisational Behaviour, 23, 593-604.

WESTIN, S. (1990) 'The structure of a Factory Closure: Individual responses to job-loss and unemployment in a 10-year controlled follow-up study' Social Science Medicine, 31 (12): 130111.

WINEFIELD, A., TIGGERMAN, M., and WINEFIELD, H. (1990) 'Factors moderating the psychological impact of unemployment at different ages' Personality and Individual Differences, 11: 45-52.

${ }^{1}$ National Australia Bank, Birmingham Business School, Birmingham Business School, the Work Foundation and Flinders University respectively. The authors wish to acknowledge the support of an ARC Linkage Grant, and the ESRC under award number RES-000-22-2478. They would also like to thank the Work Foundation and BBC Radio 4 for their contribution to the UK case study, which draws on the findings of Armstrong (2006).

2 Casual employment in Australia was traditionally defined as comprising a catch-group of flexible, contingent workers who did not receive annual leave or sick leave (De Ruyter and Burgess, 2003).

${ }^{3}$ Simply attracting FDI does not help this situation, as inward FDI tends to increase the demand for skilled labour and reduces demand for unskilled labour (see Bailey and Driffield, 2007), suggesting the need for a more holistic approach to industrial policy and economic development.

${ }^{4}$ It should be noted that the response at the regional level was much more positive, with the local Regional Development Agency Advantage West Midlands pursuing a modernisation and diversification agenda in the five years before the MG Rover collapse, which helped suppliers diversify away from the firm and which saved several thousand jobs (Bailey and Kobayashi, 2006).

${ }^{5}$ Beyond February 2006, virtually nothing is known about the remaining MGR workers still unemployed, the long term impact of those on long term benefit, and in particular the impact of the closure on the wider community and stakeholders in the region. Indeed, House of Commons (2007) notes the wide differences in estimates of employment rates of former MGR workers and the lack of information on the wider impacts of the closure. 